GUZMÁN DALBORA, José Luis "Un penalista en pugna con los lugares comunes:

Francisco Grisolía Corbatón (1928-2005). Estudio necrológico"

Polít. crim. Vol. 6, No 12 (Diciembre 2011), Doc. 1, pp. 474 - 494.

[http://www.politicacriminal.cl/Vol_06/n_12/Vol6N12D1.pdf]

\title{
Un penalista en pugna con los lugares comunes: Francisco Grisolía Corbatón (1928-2005). Estudio necrológico.
}

\author{
José Luis Guzmán Dalbora*
}

SUMARIO: 1. De los lugares comunes y nuestro autor.- 2. Linaje, vicisitudes, impronta. - 3. Formación y rendimiento hasta el quiebre de 1973. - 4. Quehacer bajo la tiranía.- 5. Los últimos años.-6. Balance.

\section{De los lugares comunes y nuestro autor.}

Llamamos en castellano "lugares comunes" a un conjunto abigarrado y sin confines de expresiones triviales, esto es, vulgarizadas y carentes de importancia, o muy socorridas para casos aparentemente análogos a aquel en que acuden como invocación. Son, pues, recursos cómodos, ordinarios y ayunos de novedad, que abundan en el magín de las gentes que han desarrollado el hábito de no pensar por su cuenta. El acefalismo intelectual, la ineptitud o pereza de comprender por nosotros mismos las cuestiones del mundo, trae consigo una drástica limitación en pensamiento $\mathrm{y}$-puesto que se habla y escribe como se piensa- ${ }^{1}$ lenguaje, defecto que es suplido prontamente por tópicos, a algunos de los cuales se acaba atribuyendo el carácter de fórmulas incontrarrestables o revelaciones inmediatas de los arcanos de la marcha del cosmos y la naturaleza del hombre. Estos son los lugares comunes.

Hay quien los atribuye a la mentalidad propia de la burguesía, ${ }^{2}$ asociación que, sin embargo, no hace justicia a la persistencia del fenómeno en todos los tiempos y grupos humanos. En verdad, el lugar común hinca sus raíces en la mentalidad prelógica o antecientífica, aquella que substituye relaciones reales por otras simplemente supuestas. ${ }^{3}$ De este reemplazo está henchido el "sentido común", que no es sino un conjunto asistemático de prejuicios, o lo que es igual, lugares comunes. Combatirlos ha sido siempre empresa dificilísima para la ciencia, porque a menudo las propias ciencias han albergado

\footnotetext{
* Catedrático de Derecho penal y de Introducción a la Filosofía jurídica y moral en la Universidad de Valparaíso (Chile).

${ }^{1}$ Reserva hecha del artista, cuya superioridad respecto de quienes no lo son radica en que él piensa más rápida y ricamente, merced a imágenes, colores o sonidos, no sólo con las lentas palabras. Este es uno de los factores de que los verdaderos artistas no gusten del trato con el mundo intelectual, y que su sola presencia resulte desconcertante y hasta ofensiva para muchos universitarios, aunque éstos ignoren la razón de su incomodidad.

${ }^{2}$ Como León Bloy, en su conocida enemiga del mundo burgués decimonónico. Véase la Exégesis de los lugares comunes. Traducción de José Mazzanti. Buenos Aires: Editorial Mundo Moderno, 1951, especialmente pp. 5 y 6.

${ }^{3}$ Forma mentis que no debe ser confundida con el pensamiento llamado salvaje, el mítico o mágico, que es tan lógico como el conocimiento científico, del que se diferencia por su intemporalidad, la captación sincrónica y diacrónica del mundo como un todo. La mentalidad a que aludimos es una variedad deteriorada del pensamiento "domesticado" con vistas a obtener algún rendimiento, de que discurre Claude Lévi-Strauss, El pensamiento salvaje. Traducción de Francisco González Arámburo. México: Fondo de Cultura Económica, 2006, cfr. pp. 317,381 y 388.
} 
GUZMÁN DALBORA, José Luis "Un penalista en pugna con los lugares comunes: Francisco Grisolía Corbatón (1928-2005). Estudio necrológico"

nociones erróneas, a las que la autoridad de quienes las formularon in thesi -piénsese en la teoría aristotélica del "justo medio" o la concepción de la verdad en la filosofía tomista-, o el interés de poderes ajenos al conocimiento científico -como el sistema geocéntrico ptolemaico-, confirieron un valor poco menos que apodíctico, rebatir el cual pudo significar, en el pasado, perder la cabeza por orden de un tribunal y, en el mejor de los casos, el ostracismo académico y abandono social del disidente. Por lo demás, el progreso científico continúa acarreando riesgos profesionales para los hombres que se atreven a cuestionar fundadamente el saber de sus mayores, cuando éste disfruta de arraigo entre quienes cultivan la disciplina de que se trate.

La Ciencia jurídica tampoco ha permanecido inmune a estos escamoteos de la razón. Incluso los ha reconocido legalmente, en lo que cabe imaginar que el autor de la ley compartió la creencia de que alguno de estos rudimentos, como en el juego de la piñata de los niños mexicanos, puede dar a veces en el blanco, ${ }^{4}$ es decir, que hizo suya la idea de que lugares y sentido común representan "sublimes ardides del pensamiento humano, nuestros medios de escapar al desconcierto en medio del irremediable flujo de la sensación". 5 Sin embargo, el enclave más persistente de aquéllos, antes que en las leyes mismas, ha sido la doctrina jurídica como tal, especialmente en cuestiones de interpretación. Prescindiendo de antecedentes antiguos, en que hubo de degenerar el ius respondendi ex ejus auctoritate y la Ley de citas durante el Imperio romano, la época de gloria de los lugares comunes (loci ordinarii) coincide con los últimos postglosadores, aferrados a la Glosa magna de Accursio (1181-1259), ${ }^{6}$ y los comentaristas y prácticos del Bajo Medioevo y primera Edad Moderna, cuando se abusó del argumento de autoridad y de la communis opinio auctorum. El afán de ahorrarse el trabajo de usar la propia Minerva contribuyó al anquilosamiento de la doctrina de los postglosadores y desencadenaría la irrisión del mos italicus, cuyos secuaces serán tildados de "verbosi in re facili, in difficili muti, in angusta diffusi". Con todo, ni la formación de la Dogmática moderna ni los prodigiosos adelantos que le granjeará la independencia de su estatuto científico merced a las grandes escuelas metodológicas de finales del siglo XIX y principios del XX, ha librado a los juristas de esa tendencia a la verbosidad en los asuntos sencillos, la imprecisión en los estrechos y el mutismo en los difíciles.

Tal vez sea precipitado expresarse así, porque son los asuntos más complejos donde acostumbran a instalarse los lugares comunes, a menudo bajo la invocación del argumento de autoridad, a propósito del cual la mudez deviene repetición de la opinión ajena. Por

\footnotetext{
${ }^{4}$ Una mención obligada en este sentido merecen las «máximas de la experiencia» en el sistema de valoración de la prueba según la reglas de la sana crítica. No es casual que el Código procesal penal chileno, entre otros ejemplos que cabría aducir del Derecho extranjero, las contraponga a los "conocimientos científicamente adquiridos" (artículo 297).

5 JAMES, William, El Pragmatismo. Traducción del inglés y Prólogo de Luis Rodríguez Aranda. Buenos Aires: Aguilar, 6 ed., 1975, p. 147.

${ }^{6}$ Entrambas fechas son inciertas.

${ }^{7}$ El juicio es de Jacobo Cujas (1522-1590). Recoge la cita CALASSO, Medioevo del diritto. I. Le fonti. Milano: Giuffrè, 1954, p. 595. Sobre los lugares comunes y el argumento de autoridad en los comentaristas, TOMÁS Y VALIENTE, Manual de Historia del Derecho español. Madrid: Tecnos, $3^{\mathrm{a}}$ ed., 1981, pp. 191192; para la communis opinio en el siglo XVI, CAVANNA, Storia del diritto moderno in Europa. Le fonti e il pensiero giuridico, 1. Milano: Giuffrè, 1982, pp. 152-155.
} 
Polít. crim. Vol. 6, No 12 (Diciembre 2011), Doc. 1, pp. 474 - 494.

[http://www.politicacriminal.cl/Vol_06/n_12/Vol6N12D1.pdf]

cierto, la autoridad corresponde a quien razona autónomamente una solución de los problemas. Cuando el razonamiento es completo, convincente y, sobre todo, acierta con la única respuesta que requiere la cuestión planteada, el acatamiento de los colegas de especialidad está justificado y, al revés, la discrepancia es sólo fruto de un prurito de vanidad, aquella que consiste en lucir el propio nombre lidiando a un estudioso de prestigio. Semejante tendencia iconoclasta, muy frecuente en la juventud, se va apagando mano a mano que el estudioso madura y el engreimiento cede plaza a la humildad, virtud indispensable en el auténtico investigador. Pero la vena de demolición es perfectamente legítima, es más, necesaria, si éste advierte que la voz autorizada razonó o planteó mal el problema, que otros la oyeron irreflexivamente y, en fin, que la solución no es lo que se supone, sino una simple tesis que ha alcanzado con el coro de los epígonos el honroso puesto de un lugar común. En la rebelión contra éstos yace la palanca que mueve el avance cognoscitivo, sea para despejar de una vez por todas los enigmas antes recubiertos con la túnica falaz de los tópicos - como el descubrimiento de la circulación de la sangre, que se logró a costa de los anatomistas griegos y la vida del que se atrevió a impugnarlos-, ${ }^{8}$ sea para aproximarse con sucesivos tanteos a su completa aclaración.

No estamos en condiciones de decidir en cuál de los miembros de la disyuntiva habría que encasillar la obra de Francisco Grisolía Corbatón, enemigo declarado de los lugares en palabra desde la juventud, pasando por la consolidación de su pensamiento criminalista, hasta los días del ocaso. Sin embargo, una cosa parécenos segura, a saber, que él obsequió a la Ciencia penal chilena con una disposición que sería recomendable atesorar, por más que la idiosincrasia local tenga dificultades para desenvolverse con la franqueza y las actitudes directas. En éstas solemos divisar, o un ataque personal o críticas destempladas, sin darnos cuenta de que al conceder preferencia a la ambigüedad, la prudencia rayana en pudibundez, incluso la hipocresía, se pasa por alto propiedades que pueden ser sumamente aprovechables en la expresión que va sin circunloquios al grano. Queremos decir con esto que también en el debate jurídico existe el peligro de comportarnos como quienes abandonan la mesa de discusión sólo porque alguien discrepa de los circunstantes y alza una enérgica voz de protesta.

A su turno, la independencia de criterio, la vehemencia en el tono al exponer los puntos cardinales de sus investigaciones dogmáticas y propuestas político-criminales, traducen en Francisco Grisolía rasgos típicos del alma española. Que parte significativa de la Dogmática penal de la España de hoy, embriagada con la ciencia de países cuyo Derecho difiere del ibérico y en muchas facetas no lo aventaja, aparente desconocer el riquísimo acervo autóctono, resulta accidental si se compara con la forma en que este autor, español de tomo y lomo, supo conservar en su quehacer criminalista lo más característico y granado de esa vieja piel de toro. Esto es digno de atención, además, en otro respecto, provisto de un valor que trasciende las consideraciones históricas, esto es, la dependencia del Derecho penal chileno respecto del español anterior al Código de 1995. Así como en la mayoría de las cuestiones de interés científico, así también para las jurídico-penales los países

\footnotetext{
${ }^{8}$ El teólogo y científico aragonés Miguel de Servet (1511-1553), quemado vivo en Ginebra. La escasa difusión de su obra Christianismi Restitutio, incinerada con el autor, explica que la ciencia médica atribuya a William Harvey (1578-1657) el descomunal hallazgo en cuestión, por ejemplo, HAYWARD, Historia de la Medicina. Traducción de Carlos M. Torres. México: Fondo de Cultura Económica, 2a ed., 1965, cfr. p. 217.
} 
GUZMÁN DALBORA, José Luis "Un penalista en pugna con los lugares comunes: Francisco Grisolía Corbatón (1928-2005). Estudio necrológico"

hispanoamericanos seguimos tomando a préstamo de Europa aquello que esperamos devolverle con creces algún día. ${ }^{9}$ Pero la deuda no será saldada en tanto en cuanto se haga abstracción de la ascendencia hispánica, con lo que nos referimos, no a adaptaciones españolas de teorías foráneas, sino a la matriz genuina, al brío singular del Derecho que se piensa y escribe en la lengua castellana.

Pues bien, Francisco Grisolía no permitió que el admirable manejo que poseyó de otros ordenamientos jurídicos lo apartase del surco español. De la apreciación de su obra y las ventajas resultantes para el país que lo acogió en la infancia, versa la presente necrología, cuyas fuentes principales son los libros, artículos, comentarios de jurisprudencia, recensiones y conferencias impresas que él publicó. Habrá también ocasión de describir fragmentos de la personalidad del creador, según el testimonio de personas de su intimidad y compañeros próximos. Lamentamos no haber podido conceder a este pliegue del asunto, medular en cualquier semblanza, la extensión que requería. El defecto nos duele por partida doble, porque al reconstruir, conforme a los datos disponibles, esta trayectoria vital, invade el ánimo la impresión de que el conocimiento personal tiene que haber sido una experiencia tan estimulante como la lectura de lo que produjo este jurista. ${ }^{10}$

\section{Linaje, vicisitudes, impronta.}

Nuestro biografiado no fue el primero de su linaje en llevar el nombre Francisco. Lo precedieron su padre, Francisco de Paula Grisolía López, y el padre de éste, abogado y, durante algún tiempo, agregado de la Legación española en Pekín.

La continuidad nominal sería escoltada por el común destino trashumante de la tríada. Nacido en el lejano oriente, Francisco Grisolía López abraza en Cataluña, región de sus ancestros, la carrera de marino mercante. Allí lo sorprende la rebelión franquista. Como buen republicano, pone lo que está en sus medios para defender al gobierno civil de la sublevación castrense. Sortea los bloqueos nacionalistas haciendo pasar armas al ejército de la República, que se desangraba en la batalla del Ebro. Esta actividad lo señalaría pronto en la lista negra de los vencedores, con serio riesgo para su vida. De hecho, cuando las huestes nacionalistas entran en Tarragona y el pánico se apodera de la población catalana, entre el medio millón de seres humanos que tomaron penosamente la ruta de la frontera con Francia

\footnotetext{
${ }^{9}$ Atendidas las condiciones sociales de aquende el Atlántico, mucho nos tememos que está lejos la "época dichosa, en que la América, a la sombra de gobiernos moderados y de sabias instituciones sociales, rica, floreciente, libre, vuelva con usura a la Europa el caudal de luces que hoy le pide prestado", esa época que Andrés Bello soñó en 1826. Cfr. Escritos jurídicos, políticos y universitarios. Selección y Prólogo por Agustín Squella Narducci. Valparaíso: Edeval (Colección “Juristas perennes”, número 5), 1979, p. 47.

${ }^{10}$ Agradezco muy especialmente a don Francisco Grisolía Cirera una copia del curriculum vitae de su padre, actualizado por éste pocos años antes de morir, así como la larga entrevista que sostuvimos sobre él promediando marzo de 2011. Vaya también nuestra gratitud a los profesores señores John MacKinnon Roehrs, por habernos facilitado el contenido de la hoja de servicios de Francisco Grisolía en la Facultad de Derecho de la Universidad de Chile; Jaime Náquira Riveros, al que debemos un esbozo de la personalidad de su amigo, así como copia de un documento en homenaje a Grisolía escrito por su discípulo, Hugo Rivera Villalobos, y Jean Pierre Matus Acuña, cuyo borrador sobre el origen, la consolidación y vigencia de la que él denomina nueva dogmática penal chilena, permitió redondear el contexto intelectual en que se movió este miembro de dicha pléyade.
} 
Polít. crim. Vol. 6, No 12 (Diciembre 2011), Doc. 1, pp. 474 - 494.

[http://www.politicacriminal.cl/Vol_06/n_12/Vol6N12D1.pdf]

marcharán él, su mujer, doña Pilar Corbatón Lozano, y un niño de nueve años de edad, nuestro Francisco, que había nacido en Barcelona el 24 de septiembre de 1928.

Consiguen cruzar la frontera con documentos falsos e instalarse provisoriamente en Niza, donde la familia permanecerá el último año de la guerra. Aquí prosigue la accidentada época escolar del hijo, en medio del desarraigo y los esperables conflictos con sus compañeritos en el colegio. Puesto que el desarrollo de los acontecimientos en el terruño natal hacía imposible siquiera pensar en la repatriación y, por otra parte, las precarias circunstancias de los refugiados, no pocos de los cuales sufrieron el cautiverio en campos de concentración, exigían arrojar alguna claridad en la incierta suerte del trance francés, la familia decide emigrar a América. El padre se las arregla para entrar en contacto con el poeta Pablo Neruda, quien había sido nombrado en el ínterin cónsul especial de emigración en Francia para traer a Chile a expatriados españoles, y consigue unos cupos para sus seres queridos. Los tres abordan el Winnipeg, de cuya azarosa travesía el niño conservará un recuerdo tan traumático como de la dolorosa salida de España y el embarque en Francia. ${ }^{11}$ Como sea, el 3 de septiembre de 1939, apenas dos días después de la invasión alemana de Polonia y el comienzo de la Segunda guerra mundial, el viejo navío, abarrotado en bodega, cámaras y cubierta con su cargamento humano, atraca en el puerto de Valparaíso. ${ }^{12}$

Las vicisitudes no cejaron de apretar en el país de acogida. El progenitor se vio en la imposibilidad de revalidar su título como marino, por lo cual hubo de emplearse en distintos oficios, hasta adquirir mayor estabilidad ejerciendo el periodismo en el diario La Nación. Por su parte, el hijo es matriculado en el Liceo Eduardo de la Barra, benemérito de la ciudad, muy ligado a los antecedentes y primeros pasos de la Escuela de Derecho de la Universidad de Chile, sede de Valparaíso, luego Universidad de Valparaíso. Una travesura escolar, la substracción del libro de clases del curso, que él y sus compañeros en la correría llenaron de palabrotas, le costó ser expulsado, ya que el mar, donde había arrojado el botín, se tomó la molestia de devolverlo a las autoridades del establecimiento. Se diría que el azar, poder tan influyente en los asuntos humanos, quiso recordarle que entre él y el solar donde pasó la primera infancia se interponía el océano, ese pozo de lágrimas a cuyo borde austral estaría atada su existencia durante un tiempo indefinido. Viaja solo a Santiago de Chile para continuar en el Liceo de Aplicación los estudios secundarios. Allí conoce y traba duradera amistad con Sergio Politoff Lifschitz (1930-2009), otro inmigrante. Andando los años, ambos serán compañeros en la Universidad, colegas penalistas y coautores de una obra de la especialidad. Pero de esto, a su momento.

Al terminar el liceo con el grado de Bachiller en Letras, en 1947, ya estaban definidos los rasgos intelectuales del joven Grisolía. Curioso, reflexivo, original, crítico, agudo al discutir y presto en la respuesta, dispuesto a reconocer los errores en sus razonamientos y a ajustar

\footnotetext{
${ }^{11}$ De hecho, al cumplirse el quincuagésimo aniversario de la llegada a Chile del barco, la Embajada española en Santiago organizó una ceremonia a la que se invitó a todos los antiguos pasajeros que quedaban en el país, para entregarles una medalla. Grisolía no quiso asistir debido a los tristísimos recuerdos que le dejó el episodio.

${ }^{12}$ Los nombres de Francisco Grisolía y sus padres, entre los dos mil doscientos pasajeros del célebre bajel, figuran en el registro reproducido por José Ferrer Mir, Los españoles del Winnipeg. El barco de la esperanza. Santiago de Chile: Ediciones Cal Sogas, 1989, pp. 122 y 128.
} 
GUZMÁN DALBORA, José Luis “Un penalista en pugna con los lugares comunes: Francisco Grisolía Corbatón (1928-2005). Estudio necrológico"

su posición, lo mismo que a ponerse en el lugar del prójimo y entender sus reacciones. Sin embargo, la garra del extrañamiento, el dolor por la patria lejana, peor, la pérdida de la nacionalidad española, a que debió renunciar para adquirir la chilena en 1951, los avatares del grupo de trasplantados ${ }^{13}$ y otros elementos que silenciamos en obsequio de la privacidad del álbum familiar, dejarían honda e indeleble impronta en la configuración de su personalidad. Grisolía será conocido en el medio universitario y forense chileno como un individuo más bien huraño, serio hasta el hermetismo, impaciente y de genio ligero, casi clausurado a la vida social. Sólo quienes supieron vencer la coraza de defensa que dejaron como sedimento los embates sufridos cuando mozo, advertirían que detrás del continente en apariencia frío, distante y malhumorado, yacían un temperamento sensible, un corazón generoso, sentimientos nobles de gratitud hacia quienes lo educaron y apoyaron en los primeros pasos de la carrera universitaria, capaz de reírse de buena gana de sí mismo y querer a los demás, apasionado por la historia y la música clásica, degustador de la comida española y francesa, apegado a la casa y amante de la familia, desde cuyo seno él edificó su obra como estudioso.

\section{Formación y rendimiento hasta el quiebre de 1973.}

Por lo pronto, en 1948 se matricula en la Facultad de Ciencias Jurídicas y Sociales de la Universidad de Chile para cursar la licenciatura en Derecho. Durante un año sigue paralelamente la carrera de Medicina, de la que tuvo que desistir para concentrarse en la formación jurídica. ${ }^{14}$ Como desquite, al egresar del período lectivo, en 1952, las clases del profesor Miguel Schweitzer Speisky (1908-1997) inclinaron su vocación hacia el Derecho penal. $^{15}$

De hecho, emprende el ambicioso proyecto de preparar su memoria de prueba o licenciatura sobre los delitos de falsedad documental, numerosos en el Código chileno. Se lo sugirió el profesor Álvaro Bunster Briceño (1920-2004), en aquellos años figura central del Seminario de Derecho penal y Medicina legal. Años más tarde, el orientador reconoció la euforia de haber estimulado una operación que sobrepasaba con largueza las posibilidades de una tesis de licenciatura, incluso lo que se espera de las de doctorado, aconsejando al alumno que presentase a la Facultad aquello que éste adelantó del descomunal asunto. Fiel a su proverbial rigor, Grisolía había invertido un cuadrienio en documentarse y reflexionar sobre las falsedades y las cuestiones de teoría de la infracción criminal involucradas, o sea, prácticamente todas. Se explica, pues, que el aparato bibliográfico, la estructura y el desarrollo argumental de la tesis, que él comprimió al objeto jurídico del delito, revele un conocimiento de la Parte general del Derecho punitivo de

\footnotetext{
${ }^{13}$ El padre no abandonó el espíritu de trotamundos típico de los marinos ni su deseo de regresar a España, lo que logra a principios de los años setenta del pasado siglo merced a una amnistía aprobada por el gobierno español de entonces. Allí se embarca de nuevo, obtiene el grado de capitán y jubila como capitán de puerto en una marina de Barcelona. El deceso de este personaje, que en no pocos aspectos es una contrafigura de su vástago, data de 1980.

${ }^{14}$ Hasta el final de sus días Grisolía se sintió frustrado por no haber sido médico. Registramos el dato para relevar la amplitud de sus intereses intelectuales.

${ }^{15}$ Sobre Schweitzer, véase una reseña en el libro Nullum crimen, nulla poena sine lege. Homenaje a grandes penalistas chilenos, coordinado por Miguel Schweitzer Walters. Santiago de Chile: Ediciones Universidad Finis Terrae, 2010, pp. 16-18.
} 


\section{Polít. crim. Vol. 6, No 12 (Diciembre 2011), Doc. 1, pp. 474 - 494. \\ [http://www.politicacriminal.cl/Vol_06/n_12/Vol6N12D1.pdf]}

inusual hondura en un aprendiz de penalista. ${ }^{16}$ La obra impresiona no sólo por el tratamiento que concede a las distintas doctrinas sobre la faz positiva de antijuridicidad, sino, principalmente, a causa de la versación iusfilosófica y el olfato político del autor. Éste inserta su decidida defensa del concepto de bien jurídico en lo que llama una fundamentación radical, esto es, una axiología material que enclava los objetos tutelados por el Derecho y ofendidos por el delito en la cultura de cada comunidad y las valoraciones sociales que informan el ordenamiento jurídico. ${ }^{17}$ De ahí, también, que apruebe la justificación supralegal y admita gustoso la naturaleza garantizadora, con el consiguiente carácter secundario del Derecho penal, una concepción harto más antigua, limitadora y garantista que la que le asigna funciones constitutivas. ${ }^{18} \mathrm{El}$ consiguiente rechazo de las interpretaciones formalistas, que desatienden la referencia estimativa de las disposiciones penales, repulsa fundada en que "la norma jurídica, como forma jurídica fundamental, implica [...] valores", los que demandan la "posibilidad y exigencia ideal de ser realizados" en bienes jurídicos, marcha en perfecta sintonía con la afirmación de que estos últimos representan "una categoría común y esencial a todo el Derecho", 19 en otras palabras, uno de los conceptos jurídicos fundamentales o a priori.

La demora en culminar la tesis, como su acelerado y feliz desenlace, corrieron parejas con las circunstancias personales de Grisolía en la década de los cincuenta. Al egresar de la Facultad emprendió un viaje de estudios a España llevando el encargo de traer a Chile a una hermana de su madre. Con la tía vivía la joven Ana Cirera Sabi, de quien Francisco quedó prendado. El hecho es que regresará a Sudamérica en compañía de las dos mujeres, unido a la segunda como flamante esposo. ${ }^{20}$ Del matrimonio nacerán cuatro hijos. ${ }^{21}$ Si hasta ese punto había podido salir adelante con los modestos ingresos de procurador, sin otros compromisos aparte del desproporcionado que se autoimpuso con la memoria de prueba, el enlace nupcial y la llegada de los dos primeros hijos tornaron imperioso ajustar el esfuerzo académico a las exigencias de licenciatura y titulación como abogado. El afán mereció holgadamente la pena. Bunster, que dirigía la Revista de Ciencias Penales del Instituto homónimo en Santiago, lo solicita a principios de 1958 para publicar en la sección "Doctrina" el escrito de graduación, que el autor cerró tras dos meses dedicado exclusivamente a la tarea. Tal era la confianza que depositaba el tutor en las fuerzas del pupilo y la calidad de su trabajo, que la tesis se publica como artículo antes de los informes universitarios del caso. ${ }^{22}$ Por cierto, éstos propondrán la calificación de sobresaliente, y el

\footnotetext{
${ }^{16}$ Lo destacan los profesores Gustavo Labatut Glena (1896-1963), Alfredo Etcheberry Orthusteguy y Miguel Schweitzer Speisky en sus informes del estudio. Cfr. GRISOLÍA, El objeto jurídico del delito. (Prolegómenos para el estudio de la objetividad jurídica en los delitos de falsedad documental), Santiago de Chile, 1959, pp. I-IV. La publicación está dedicada a Schweitzer, por quien el discípulo continuará nutriendo sentimientos de gratitud y devoción.

${ }^{17}$ En Filosofía general, asume la teoría de los valores de Max Scheler y Nicolai Hartmann, a los que estudió en versiones castellanas de obras del primero y en la adaptación jurídica del pensamiento del segundo realizada por Luis Recasens Siches. En este último se inspira principalmente la filosofía jurídica del libro.

${ }^{18}$ El objeto jurídico del delito, cit., cfr. pp. 23-25, 27-53 (las de mayor densidad filosófica) y 80-83.

19 Ídem, pp. 41, 49 y 53.

${ }^{20}$ Se casaron en Barcelona el 8 de julio de 1953.

${ }^{21}$ Francisco (1957), médico-cirujano; Leonor (1958), profesora de inglés; Beatriz (1960), diseñadora gráfica, y Eugenia (1964), licenciada en Biología.

22 "El objeto jurídico del delito", en la Revista de Ciencias penales, de Santiago de Chile, Tercera época, septiembre-diciembre de 1958, número 3, tomo XVII, pp. 3-85.
} 
GUZMÁN DALBORA, José Luis “Un penalista en pugna con los lugares comunes: Francisco Grisolía Corbatón (1928-2005). Estudio necrológico"

Instituto galardonará al escritor con el premio "Pedro Ortiz Muñoz", que se le entregó en 1959. Un año después obtiene el título de abogado. Sin embargo, éste era sólo la culminación de un proceso cuyo efecto lo ligaría de por vida a la Facultad de Derecho y al Instituto de Ciencias Penales. El progreso de la memoria de prueba, que lo señaló a sus profesores cual risueña promesa en la investigación y enseñanza de la atroz materia, dio frutos que precedieron la completa sazón, parecidamente a la suerte gráfica de la tesis. Grisolía había sido nombrado ayudante de la cátedra de Derecho penal en 1957 y del Seminario de Derecho procesal, área de proceso penal, en 1959. Desde 1954 ocupaba los cargos de secretario ejecutivo del Instituto y de redacción de la Revista de Ciencias Penales.

La década siguiente lo ve enfrascado en un febril empeño de perfeccionamiento académico, investigación, enseñanza y ejercicio profesional, con dos teatros geográficos de actividad, Europa y Chile. ${ }^{23}$ Se trata de múltiples ocupaciones que se entremezclan y potencian unas con otras, por lo que conviene resumirlas al hilo de su secuencia cronológica.

En enero de 1961 el alma mater lo convierte en profesor auxiliar de Derecho penal. Unos meses antes, durante 1960, había frecuentado un curso de Derecho penal y procesal penal francés en la Universidad de París, bajo la guía de los profesores Robert Vouin y Marc Ancel. La Dogmática y, sobre todo, la reforma del proceso penal interesaban sobremanera a Grisolía. Presenta al Instituto un plan de investigación cuyo objeto era generar un anteproyecto que sirviese de base para la reforma total del vetusto y autoritario Código de procedimiento penal chileno (1906). La iniciativa suponía profundizar el estudio teórico y embeberse de la aplicación del proceso penal en España, Argentina (Provincia de Córdoba), Francia e Italia. El Instituto apoyó financieramente el proyecto, que adquiere carácter oficial con el respaldo prestado por el Gobierno y la Universidad de Chile. En 1961 se empapa en Madrid y Barcelona del funcionamiento del proceso español, ${ }^{24}$ presenciando audiencias judiciales y entrevistándose con diversos especialistas, negocios que repite en París y, al año siguiente, en la Argentina, donde su trabajo fue grandemente facilitado por la ayuda de Alfredo Vélez Mariconde. El informe final al Instituto ${ }^{25}$ condensa una pieza de genuino Derecho comparado, que no es lo mismo que mera confrontación de legislaciones, siendo de lamentar que los gobiernos de la época, también inquietos por modificar el Código, optasen por adecuarlo a un proceso de características mixtas, ${ }^{26}$ no ya gestar uno realmente novedoso, como quería Grisolía. ${ }^{27}$

\footnotetext{
${ }^{23}$ Poco antes, fue secretario técnico de las Segundas Jornadas chileno-uruguayas de Derecho comparado (Santiago de Chile, 1959).

${ }^{24}$ Llegó a España desde Lisboa, ciudad en la que asistió, como miembro de la delegación chilena, al VII Congreso de la Asociación Internacional de Derecho penal.

25 "Investigación sobre Derecho procesal penal comparado", en la Revista de Ciencias penales, cit. nota n²2, enero-abril de 1963, número 1, tomo XXII.

${ }^{26}$ Nos referimos al proyecto elaborado por el ministro de Justicia Enrique Ortúzar Escobar, que separa las funciones de juez instructor y jueces sentenciadores, y el del magistrado Rubén Galecio Gómez, que buscó, además, restablecer el ministerio público en su función acusadora de primera instancia, perdida con la supresión del servicio en 1927, imprimir celeridad a los juicios mediante el procedimiento condensado o urgente, y apuntalar los derechos y la defensa del inculpado dentro del sumario.

${ }^{27}$ Éste no cejará en el intento. El gobierno lo designa en 1968 miembro de la comisión redactora de un proyecto de reforma del Código de procedimiento penal y, en 1971, miembro de la comisión redactora de otro
} 
Polít. crim. Vol. 6, No 12 (Diciembre 2011), Doc. 1, pp. 474 - 494.

[http://www.politicacriminal.cl/Vol_06/n_12/Vol6N12D1.pdf]

En 1962 gana por concurso el cargo de abogado de la Superintendencia de Seguridad Social. Paralelamente, imparte clases de Derecho penal en la Universidad y redacta comentarios a sentencias, reseñas y recensiones en la Revista de Ciencias Penales. El lazo con el Instituto se estrecha aún más al asumir en 1963 como subsecretario ejecutivo de la comisión redactora del Código penal tipo para Latinoamérica, una iniciativa personal del hombre que presidía entonces la entidad, Eduardo Novoa Monreal (1916-2006). A su lado trabajará intensamente en las reuniones plenarias de la comisión (Santiago de Chile, 1963; México, 1965; Caracas, 1969; Bogotá, 1970; São Paulo, 1971; San José de Costa Rica, 1972, y Medellín, 1973). ${ }^{28}$ El contacto con colegas de otros países del continente y los trabajos preparatorios del Proyecto amplían sus conocimientos iuscomparatistas hasta dominar como pocos la legislación iberoamericana. ${ }^{29}$

No sólo eso. Grisolía sabrá encauzarlos hacia el doctorado. En goce de una beca del Instituto de cultura hispánica se traslada en 1966 a Madrid. Su dedicación al trabajo, que ha de haber optimizado al máximo el tiempo disponible si se considera que compartieron la estancia matritense su mujer y los cuatro niños, cristaliza en varios logros: la revalidación de la licenciatura, un diploma de especialización por la Organización Iberoamericana de Seguridad Social y, naturalmente, el doctorado en Derecho, que le extiende con nota de sobresaliente la Universidad entonces llamada Central, hoy, Complutense. Amén de la tesis doctoral, que trató del Código penal tipo, ${ }^{30}$ alumbra dos interesantísimos artículos, uno sobre el sistema chileno de seguridad social ${ }^{31}$ y el segundo intitulado "La reforma penal en Chile." 32 Aquí despliega una límpida exposición de la historia del Derecho penal chileno, desde el período aborigen y colonial hasta el Código de 1874, con los intentos de reforma total en el siglo XX. Además, la labor del Instituto y la evolución de la Ciencia penal

sobre procedimiento concentrado y juicio oral. En 1974 integró las comisiones ministeriales de reforma a los Códigos penal y procesal penal.

${ }^{28}$ Las restantes (Santiago de Chile, 1974; San Cristóbal, 1976; Madrid, 1978, y Buenos Aires, 1979) ocurren con Novoa y otros penalistas chilenos en el exilio. En el siguiente apartado se dirá que los sucesos de septiembre de 1973 infligieron al Instituto y sus actividades, como a todo el país, un golpe del que no conseguirían recuperarse hasta el presente. Una cumplida información y un juicio crítico del Proyecto en palabra, en RIVACOBA y RIVACOBA, Pensamiento penal y criminológico del Código penal tipo para Iberoamérica, en: NAVARRETE, Polaino (compilador), Estudios jurídicos sobre la reforma penal. Córdoba (España): Servicio de Publicaciones de la Universidad de Córdoba, pp. 215-244.

${ }^{29}$ De estos años datan varios artículos en colaboración con Eduardo Novoa Monreal, a saber, "Suggestions pour l'organitation d'estudes preparatoires d'un Projet de Code penal type", en la Revue Internationale de Droit pénal, París, números 1 y 2, primer y segundo trimestres de 1965; "Proyecto de Código penal tipo para Iberoamérica", en Lecturas Jurídicas, de Chihuahua, número 14, enero-marzo de 1963; "Proyecto de Código penal tipo para Iberoamérica". Antecedentes, plan de trabajo, documentos preparatorios, Santiago, 1963; "Proyecto de Código penal tipo para Latinoamérica", en la Revista de Derecho español y americano, de Madrid, año VIII, $2^{a}$ Época, 1963; "Proyecto de Código penal tipo para Latinoamérica", en La Ley, de Buenos Aires, 1971, y "Vers un project de Code penal type pour l'Amerique Latine", en Revue de Science criminelle et de Droit pénal comparé, de París, número 1, 1964. Véase, también, sólo de GRISOLÍA, "Estudios sobre los antecedentes, orígenes y labores de la Comisión redactora del Código penal tipo para Latinoamérica", en la Revista Mexicana de Derecho penal, número 4, 1971.

${ }^{30}$ El Código penal tipo para Hispanoamérica: proceso formativo y estudio crítico. Madrid, 1967.150 págs.

31 "Esquema crítico de la Seguridad Social chilena", en la Revista Iberoamericana de Seguridad Social, número 4 del año XVI (1967).

${ }^{32}$ Se publica en el Anuario de Derecho penal y Ciencias penales, de Madrid, t. XX, fascículos I y II, eneroagosto de 1967, pp. 289-332. 
GUZMÁN DALBORA, José Luis "Un penalista en pugna con los lugares comunes:

Francisco Grisolía Corbatón (1928-2005). Estudio necrológico"

vernácula, que el autor enjuicia con imparcialidad, comparecen resumidas por el artículo, escrito en un castellano correctísimo y con un estilo que será característico de aquél, preciso en las palabras, económico en las frases, enemigo de los rodeos, franco en las ideas, de prudente elegancia. Llama la atención sobre los sectores todavía descuidados del ordenamiento chileno, particularmente los delitos singulares y la teoría de la pena. ${ }^{33}$ Sin embargo, elogia las bondades del Derecho penal codificado, menos imperfecto que el de otros países y que puede dar más de lo que se imagina si se lo explora en todos sus pasajes y posibilidades. Este pensamiento de Grisolía no riñe con su entrega al Código penal tipo, del que informa sintéticamente el pliego. Al ocuparse de la necesidad, el ámbito y las prioridades de la reforma penal, en las páginas conclusivas, que compendian el ideario político-criminal del novel doctor, discrepa de la obsesión reinante por contar con un nuevo Código, como si éste fuese la panacea del problema de la criminalidad, mientras en el país se posterga sine die acometer aspectos mucho más graves, urgentes y de enorme significado práctico, esto es, la ejecución de las penas y el proceso criminal. La tabla de prioridades legislativas que él propone coloca estas dos tareas en el primer lugar, seguidas de una modificación parcial del Código penal y, a largo plazo, "una vez logradas las condiciones mínimas que posibiliten su aplicación práctica y eficaz", la de "promover la implantación de un nuevo Código penal que, mientras tanto, se habrá preparado con la debida calma, sobre la base del Proyecto de Código penal tipo para Latinoamérica y de las premisas que orientan su formación". 34

No era la primera oportunidad en que se manifestó así, ${ }^{35}$ bogando contra la corriente, ni será la última. La exactitud de la previsión de que la reforma del procedimiento penal es factible sin tener que aguardar la sanción de un cuerpo punitivo, supuesto que la orientación política y las directrices técnicas de los textos sean unas mismas, sería confirmada por la marcha legislativa del país. ${ }^{36}$ Desgraciadamente, el paso de los años no consiguió remover otros lugares comunes combatidos por la propuesta de 1967, comenzando por la regulación y la estremecedora realidad de la ejecución de las penas, que continúa sumida en la ilegalidad, desprovista de una judicatura especializada -en verdad, de la jurisdicción tout court-, invadiendo más derechos que los afectados legalmente por la sentencia de condena, en medio del hacinamiento, la violencia, abusos de toda clase, revueltas y, en el último tiempo, para festín de la opinión colectiva y escarnio de los poderes públicos, la hoguera de los reclusos. Este punto, pero también la recurrente objeción de que el país no está en condiciones de invertir más recursos materiales y humanos en el cumplimiento de las penas, es uno de los muchos en que sigue triunfando el sentido común peculiar del pueblo chileno, con la consideración del preso como un ser indigno de la calidad de persona, pese a

\footnotetext{
${ }^{33}$ Lagunas del conocimiento que, desafortunadamente, han permanecido en buena medida intactas hasta el día de hoy.

34 “La reforma penal en Chile", cit. nota ${ }^{\circ} 32$, pp. 331-332.

${ }^{35}$ Véase su comentario jurisprudencial en la Revista de Ciencias Penales, cit. nota n 22, número 3, 1964, tomo XXIII, pp. 283-284.

${ }^{36}$ Grisolía, empero, no quedó conforme con el Código procesal penal, aprobado el año 2000, al que juzgó "americanizado" en exceso. Y hay que decir que no andaba descaminado al privilegiar el modelo acusatorio europeo.
} 
Polít. crim. Vol. 6, No 12 (Diciembre 2011), Doc. 1, pp. 474 - 494.

[http://www.politicacriminal.cl/Vol_06/n_12/Vol6N12D1.pdf]

que estos problemas, además de su inmensa trascendencia individual y familiar, "afectan en forma esencial la seguridad y el normal desarrollo de la vida colectiva de la nación". ${ }^{37}$

De vuelta en Chile, asume la dirección de la Revista de Ciencias Penales (1967). Desde este cargo fortalece la regularidad que había adquirido la publicación, organiza jornadas académicas, apoya el enriquecimiento de la biblioteca del Instituto, cultiva el trato personal y la colaboración científica con compañeros penalistas. De este círculo fueron amigos o disfrutaron de su admiración o respeto intelectual, Juan Bustos Ramírez (1935-2008), Sergio Yáñez Pérez (1925-2006), Sergio Politoff Lifschitz y Jaime Vivanco Sepúlveda, además de Novoa, Schweitzer y Bunster, y los más jóvenes Jaime Náquira Riveros, Hugo Rivera Villalobos -su discípulo en la Universidad, pasante y luego socio del despacho profesional- y Jorge Mera Figueroa. Especial cariño profesará a Manuel de Rivacoba y Rivacoba (1925-2000), quien llegó a Chile desde la Argentina y al que lo hermanaban España y las imborrables secuelas internas del exilio.

En 1971 obtiene por concurso público de oposición y antecedentes la calidad de profesor agregado de Derecho penal. El mismo año aparece publicado el primer tomo de una obra sobre la Parte especial de Derecho penal chileno, que firma con Juan Bustos y Sergio Politoff, sus compañeros en la Facultad. ${ }^{38}$ Al trazar la semblanza de este último explicamos que fue Politoff el verdadero autor del libro, a lo que añadimos, sin embargo, que "la aclaración cede en importancia si se recuerda los lisonjeros juicios que en el Prólogo dedica a las tres figuras don Luis Jiménez de Asúa (1889-1970), a lo largo de párrafos que tornan superfluo comentar a nuestra vez un texto bien armado, completo dentro de su limitación, de redacción precisa y elegante, muy indicado para el aprendizaje de los delitos contra el individuo en sus condiciones físicas, asaz gravitante en la jurisprudencia y superior a otros de su género que habían aparecido en el ínterin". ${ }^{39}$ El propio Jiménez de Asúa, a renglón seguido de la notación de los azares de la vida de su coterráneo y calificar como eminente lo escrito por él hasta este hito editorial, expresa que el libro es el resultado de una colaboración favorable y amplia, atendida la distinta formación europea de los tres jóvenes profesores. ${ }^{40}$ Con efecto, en el aparato bibliográfico, proporcionada y pertinentemente distribuido entre fuentes alemanas, españolas e italianas, que amplifican considerablemente el sustento nacional, se percibe el aporte de Grisolía con su dominio de las obras hispánicas. Asimismo, el texto deja entrever su influjo a través de Politoff, por ejemplo, en el alcance de la voz «circunstancias» dentro del sistema del Código -tema que aquél

\footnotetext{
${ }^{37}$ Razón por la cual "el Estado se encuentra ante el inexcusable deber de sufragar, como sea, los gastos en su mínimo indispensable". "La reforma penal en Chile", cit. nota n³2, p. 331.

${ }^{38}$ Derecho penal chileno. Parte especial. Tomo I (único publicado). Santiago de Chile: Ediciones Encina, 1971 (con varias reimpresiones por distintas editoriales; la última, en 2006).

39 GUZMÁN DALBORA, "Estudio necrológico: Sergio Politoff Lifschitz o la perseverancia creadora de una vida emigrante." En Cuadernos de Política Criminal. Madrid: Edersa (Editoriales de Derecho Reunidas), número 100 (2010), pp. 275-302. Además, en Revista de Estudios de la Justicia, Centro de Estudios de la Justicia de la Facultad de Derecho de la Universidad de Chile, Santiago de Chile, número 12 (2010), pp. 1339, y en Política Criminal. Revista electrónica semestral de políticas públicas en materias penales. Centro de Estudios de Derecho penal de la Universidad de Talca, Santiago de Chile, número 8 (2009), D1-9, pp. 1-20, disponible en internet, http://www.politicacriminal.cl/n_09/d_1 9.pdf

${ }^{40}$ Cfr. BUSTOS/GRISOLÍA/POLITOFF, Derecho penal chileno, op., vol. et ed. cits., pp. 10-12.
} 
GUZMÁN DALBORA, José Luis "Un penalista en pugna con los lugares comunes: Francisco Grisolía Corbatón (1928-2005). Estudio necrológico"

desarrollará por su cuenta un lustro más tarde-- ${ }^{41}$ Quién sabe si ciertos juicios críticos, de los escasos no matizados por el humor socarrón del redactor, deban parte de su fogosidad al español que cooperó al perdurable éxito editorial del volumen.

Grisolía no olvidará al prologuista. Con motivo del fallecimiento de éste, ocurrido en noviembre de 1970, el Instituto de Ciencias Penales organiza unas sesiones especiales en Santiago y Valparaíso como homenaje póstumo al celebérrimo criminalista, cuyo nombre llevó por años una de las aulas del organismo. La intervención de Grisolía, reproducida en la Revista con las demás que se leyó en la oportunidad, subraya la influencia del magisterio de Jiménez de Asúa sobre las nuevas generaciones de penalistas hispanoamericanos, la prodigiosa juventud del espíritu del madrileño y lo determinante que resultaron su titánica productividad y ejemplo personal así en la vocación como en el ulterior trabajo del catalán avecindado en Chile. ${ }^{42}$

El curso de las cosas no hacía presagiar aún las dimensiones de la catástrofe que desde el refugio de las sombras aguardaba la ocasión propicia para cernirse sobre el país, su Instituto criminalista y la Universidad. Todavía era hora de trabajar, como lo son todas -buenas o malas, duras o maduras- las de un estudioso. Siempre en la calidad de secretario del Instituto y director de la Revista, Grisolía participa como delegado en el Coloquio internacional que promovió el primero en abril de 1973 acerca de la pena y su ejecución, con un estudio de la remisión y la libertad condicionales, escrito en coautoría con Jaime Náquira y Jaime Vivanco. ${ }^{43}$ Aquí torna a la carga contra la ilegalidad y el imperio de la discrecionalidad administrativa, no sólo en esa pareja de vicisitudes de la punición, sino en toda la fase de cumplimiento, para la que recomienda, de nuevo, la creación de una judicatura especial, el juez de ejecución de penas. El mismo año las librerías de Santiago mostrarán en sus escaparates la Parte general del Código penal tipo, en tres volúmenes que recogen los antecedentes, ponencias, acuerdos y discusiones de este proyecto doctrinal. ${ }^{44}$ Pero al minucioso esfuerzo compilador del subsecretario ejecutivo de la comisión que lo redactó, con los esperanzadores tonos de celeste y azul que ornan la portada del libro, hará cruel contraste la violácea ruina del país.

\footnotetext{
${ }^{41}$ El libro con sus colegas lo toca de pasada en la cuestión de la incomunicabilidad a partícipes extranei del parentesco como elemento típico del delito de parricidio. Ídem, cfr. p. 128.

42 "En el desempeño de mis actividades posteriores, no recuerdo haber podido componer algún artículo, escrito de fondo, nota jurisprudencial o material de clases, sin el apoyo bibliográfico de las obras de Jiménez de Asúa; sin sus ideas en numerosas oportunidades". "Jiménez de Asúa y las nuevas generaciones de penalistas", en la Revista de Ciencias Penales, enero-junio de 1971, número 1, tomo XXX, p. (9-11) 10. Años antes Grisolía preparó una recensión del tomo VI del Tratado de aquél. Cfr., de la misma Revista, el número 3, septiembre-diciembre de 1963, tomo XXII, pp. 364-367. Es muy exacta su apreciación de que el carácter enciclopédico, que indiscutiblemente posee el Tratado, y la colosal erudición del autor, no restan un ápice al sello y la elaboración originales de las ideas que éste va entramando en la discusión del pensamiento ajeno. Harían bien los jóvenes doctores en aprender de esta manera de investigar, renunciando de una vez por todas al enojoso apartado "toma de posición" o "postura personal", que se suele leer en las tesis y monografía actuales a remolque de la exposición, interminable y fastidiosa, de las ideas de otros, un procedimiento que traiciona que el autor piensa a medida que escribe, no escribe lo ya organizado en su pensamiento.

43 "La remisión condicional de la pena y la libertad condicional en el sistema chileno de ejecución de las sanciones", en la Revista de Ciencias Penales, enero-abril de 1973, número 1, tomo XXXII, pp. 93-110.

${ }^{44}$ Cfr. Código penal tipo para Latinoamérica. Materiales publicados bajo la dirección del Prof. Francisco Grisolía Corbatón. 3 vols. Santiago de Chile: Editorial Jurídica de Chile, 1973.
} 
Polít. crim. Vol. 6, No 12 (Diciembre 2011), Doc. 1, pp. 474 - 494.

[http://www.politicacriminal.cl/Vol_06/n_12/Vol6N12D1.pdf]

\section{Quehacer bajo la tiranía.}

Los hechos de septiembre de 1973 hicieron revivir en la memoria de los Grisolía la experiencia del asedio de Barcelona y la huida a Francia, llenando de espanto a los mayores de la familia. La casa, en calle Torremolinos, distaba pocas manzanas de la residencia presidencial, por lo que pudieron oír de cerca el estruendo de las bombas que arrojaron los aviones en el edificio de la avenida Tomás Moro, luego allanado, saqueado y expropiado por los militares. Don Francisco temió por los suyos. No le faltaban motivos, porque, pese a haberse abstenido de intervenir activamente en política, lo ocurrido en España y aquello que desencadenaría la sedición en Chile son prueba de que tampoco era en absoluto necesaria la filiación partidista, ni siquiera la comunidad ideológica con pensamientos adversos a los de la oligarquía rebelde, para sufrir el furor persecutorio de las nuevas autoridades. Además, los nombres de algunos amigos, como Juan Bustos y Sergio Politoff, aparecieron en los primeros bandos entre las personas requeridas de presentación, y nuestro biografiado sabía que eso sólo podía significar la muerte o huir del país para evitarla, el camino que tuvieron que emprender sus camaradas en la universidad.

Asimismo, el golpe de Estado lo afectó profesionalmente. Hombre de ideas de centro, desaprobaba los lineamientos de seguridad social de los individuos que estaban detrás de la Junta de gobierno. Su conciencia le impidió pasar del alto puesto de fiscal en la Superintendencia de Seguridad Social, que ocupaba en ese trance, al de jefe máximo del servicio, y se retira voluntariamente de él en 1974. Poco más de un lustro después confirmará la exactitud de su determinación cuando dos decretos-leyes transforman de un plumazo el sistema de seguridad social chileno en otro de seguros mercantiles de salud y especulación en las pensiones. Grisolía se recluye en el Instituto y el despacho de abogado. Con el exilio de la mayoría de sus miembros más conspicuos y activos, las divisiones que enfrentaron a esa generación y la atmósfera de oscuridad que cayó sobre todas las manifestaciones del cultivo de ciencias y artes, el Instituto queda desarticulado, pierde la presencia pública que poseía, decae notoriamente la periodicidad de su revista, menguan los cónclaves y conferencias que prodigó antaño. Ha de haber sido sumamente difícil trabajar en semejantes condiciones para el secretario ejecutivo de la entidad y director de la publicación, puestos que Grisolía conservó hasta principios de los años noventa, ${ }^{45}$ década en que empieza a jubilar de sus destinos, salvo la creación intelectual, como diremos en el acápite siguiente. De momento, empero, incluso ésta tuvo que ponerse a tono con las nada halagüeñas circunstancias. Basta pensar en una nota jurisprudencial donde aborda la liberación de los presos preventivos según las actas "constitucionales", esas relaciones escritas de lo que acordó con pretensiones de fundación jurídica la cuadrilla instalada en el palacio de gobierno. ${ }^{46}$ Como contrapartida, representa a la Revista de Ciencias Penales en

\footnotetext{
${ }^{45}$ En su currículum registra el año 1992 como el de cese en la dirección de la Revista de Ciencias Penales.

${ }^{46}$ Cfr. Revista de Ciencias Penales, julio-diciembre de 1975, número 2, tomo XXXIV, pp. 208-215. Despojado del lamentable entorno ocasional, el comentario reviste valor por su firme defensa de la libertad del inculpado como la regla en el proceso, puesto que "el mal llamado 'beneficio' de la libertad provisional es un derecho que procederá siempre, es decir, en todo caso y con respecto a todo delito, cualquiera que sea la nominación o entidad punitiva", y el rechazo de las disposiciones denominadas "programáticas" en una Constitución, esto es, principios carentes de poder preceptivo mientras no los desarrolle la ley. Esta suposición, que para el comentarista es un mito nacido "de una curiosa pacatería interpretativa cuyo éxito no logramos entender", gozaba, en efecto, de mucho predicamento en aquellos años.
} 
GUZMÁN DALBORA, José Luis “Un penalista en pugna con los lugares comunes: Francisco Grisolía Corbatón (1928-2005). Estudio necrológico"

las Jornadas internacionales celebradas en la sede de Valparaíso de la Universidad de Chile, con ocasión de cumplirse en 1974 el centenario del Código penal. El nervio democrático de éste y el temple liberal del promotor y presidente del evento, Manuel de Rivacoba y Rivacoba, ofrecían la antítesis perfecta de las abominables condiciones circundantes. ${ }^{47}$

Poco tiempo después aparece un excelente estudio sobre el problema del carácter accesorio de la participación de sujetos no cualificados en delitos especiales. ${ }^{48}$ El tema presentaba un doble interés. De un lado, dogmático, dada la tendencia de los tribunales y parte de la doctrina a extender el título especial de imputación al partícipe extraneus, no sólo en los de malversación de caudales públicos y fraude al Estado o a entes públicos menores, eje temático del texto, sino en todos los delicta propia, como el parricidio. De otro, político, por la propensión de los regímenes autoritarios a aniquilar la diferencia entre autores y partícipes, sometiendo a la misma pena a quienes de algún modo tuvieron relación, por lejana que fuere, con los maleficios que teme el detentador del poder, principalmente, el terrorismo. $^{49}$ Pues bien, el articulista, como es natural, sustenta la teoría diferenciadora, y distingue cuidadosamente las formas de autoría y de participación en el Código chileno fundándose en criterios normativos que, empero, consideran la base naturalista de los actos humanos. La combinación de estos dos puntos de vista, normativo y descriptivo, resplandece en la médula del trabajo, la comunicación del título de imputación al partícipe no funcionario en los delitos contra la Administración pública, que Grisolía considera "un problema artificial creado deliberadamente, toda vez que el asunto se encuentra resuelto por una precisa norma legal, el artículo 64 inciso primero del Código penal". ${ }^{0}$ Hay que reconocer que a la inteligencia extensiva de la voz "circunstancias" había llegado años antes un grupo minoritario de penalistas españoles en su examen del precepto de que proviene el chileno; ${ }^{51}$ pero Grisolía amplía y mejora la cadena argumental de sus antecesores mediante un impecable empleo de los métodos sistemático y teleológico de interpretación de la ley. ${ }^{52}$ El corolario fluía evidente: una excepción en los delitos especiales impropios al carácter accesorio de la participación, en la nomenclatura hispánica, la incomunicabilidad a ésta de los ingredientes personales o subjetivos en el autor. Sin embargo, para Grisolía no estamos frente a una situación excepcional. Que el partícipe no cualificado haya de responder por el delito común tampoco implica anular la teoría unitaria de la codelincuencia; al contrario, ratifica su verdadero contenido, porque la unidad de las contribuciones de los copartícipes lo es con respecto del hecho, en otras palabras, el acto

\footnotetext{
${ }^{47}$ La intervención de Grisolía está documentada en Actas de las Jornadas internacionales de Derecho penal en celebración del centenario del Código penal chileno. Edición y Prólogo de Manuel de Rivacoba y Rivacoba. Valparaíso: Edeval, 1975, cfr. pp. 233-234.

48 "La comunicabilidad en los delitos de malversación y fraude". Separata de la Revista de Ciencias Penales, tomo XXXIV, número 1, 1975.

${ }^{49}$ La historia, incluso nuestros días, revelan que este no es un problema circunstancial ni privativo de las dictaduras. Componentes autoritarios enquistados en las democracias modernas han conseguido descalabrar la distinción de autores y partícipes en los delitos de su sílabo, que se va extendiendo rápidamente desde el terrorismo y las asociaciones ilícitas hacia el tráfico de drogas, la producción de pornografía con menores de edad, etc. Sobre el particular, Hurtado Pozo, Manual de Derecho penal. Parte general, I. Lima: Grijley, $3^{\mathrm{a}}$ ed., 2005, cfr. pp. 911-913.

50 "La comunicabilidad en los delitos de malversación y fraude", cit. nota ${ }^{\circ} 48$, p. 3.

${ }^{51} \mathrm{O}$ sea, el artículo 60 del antiguo Código hispano (art. 65 del Código de 1995). Véase CÓRDOBA RODA, en Comentarios al Código penal. 3 vols. Barcelona: Ariel, t. II, 1972, p. 252.

52 "La comunicabilidad en los delitos de malversación y fraude", cit. nota n 48, cfr. pp. 29-37.
} 
Polít. crim. Vol. 6, No 12 (Diciembre 2011), Doc. 1, pp. 474 - 494.

[http://www.politicacriminal.cl/Vol_06/n_12/Vol6N12D1.pdf]

como primer elemento del delito, del que luego el juez predicará el juicio de tipicidad y las valoraciones que atienden en los restantes elementos de la infracción penal. En síntesis, la "accesoriedad al hecho" ministra la base para "enfrentar debidamente el mito de la pretendida "indivisibilidad del título" (principio de unidad), como razón de comunicabilidad". 53

De 1975 en adelante Francisco Grisolía mantiene la pluralidad de sus campos de operación. Dicta charlas en Argentina, Colombia, España, México y Venezuela, así como en cortes nacionales de apelaciones y el colegio de abogados chileno. Con su asombroso manejo de la biblioteca del Instituto guía a los jóvenes licenciandos que acudían a él en busca de orientación bibliográfica. ${ }^{54}$ Organiza un acto en memoria de Daniel Schweitzer Speisky (1896-1979), durante el cual se dio el nombre de éste al segundo salón del recinto de calle Huérfanos. ${ }^{55}$ Ejerce intensamente como abogado criminalista, función en la que brilló por la meditada estrategia en la preparación de los juicios, particularmente en causas sobre delitos patrimoniales, que eran su especialidad, ${ }^{56}$ el rigor en los alegatos, la pasión que imprimía a las defensas orales, la serena dignidad ante los fallos, positivos o desfavorables, y el respeto hacia el defensor de la contraparte -en privado, sin embargo, confidenciaba el desprecio que le merecían los letrados que presumen de conocimientos que no poseen o gustan de aparecer en televisión, llamándoles faranduleros, palabra con que en nuestro idioma se significa a comediantes y charlatanes-. Dicta sus clases en la Universidad de Chile, también de postgrado, área en que explicó los años 1984-1986 un curso de delitos económicos. ${ }^{57}$ Pero la cátedra en la disciplina había demorado mucho, tal vez más de lo razonable. ${ }^{58}$ Acaso por ello a principios de ese decenio consideró seriamente la oferta de cambiar de país y enseñar Derecho penal en la Universidad de Puerto Rico. Por fin, en 1987 la Universidad de Chile se decide a reconocer la trayectoria académica de una de las mejores figuras de su claustro nombrándole profesor titular, equivalente al catedrático español.

\section{Los últimos años.}

La cima universitaria toca a Grisolía casi sexagenario. La tardanza del suceso, faltándole apenas siete años para el umbral del retiro, no distraería del trabajo a un individuo cuyo temple se forjó en la adversidad. Después de jubilar de las tareas universitarias continúo prestando servicios como asesor para asuntos penales. Pero lo más interesante de la fase final de su existencia es la intensificación de la vena publicista y el tono crítico del escritor.

\footnotetext{
53 "La comunicabilidad en los delitos de malversación y fraude", cit. nota $n^{\circ} 48$, p. 22. En páginas 20-21 desarrolla el razonamiento al hilo de las indicaciones de Gonzalo Rodríguez Mourullo y Giuseppe Bettiol, el máximo representante de la Jurisprudencia de los valores en Italia.

${ }^{54}$ Recuerda su generosa disposición hacia los estudiantes la nota necrológica de Vivian Bullemore Gallardo, "En memoria de Francisco Grisolía Corbatón", publicada por La Semana Jurídica, de Santiago de Chile, número 239, semana de 6 a 12 de junio de 2005.

55 Puede consultarse las palabras que pronunció en recuerdo del hermano de su maestro en la Revista de Ciencias Penales, cit., 1978-1981, tomo XXXVII, vol. II, págs. 195-196.

${ }^{56}$ Hasta 2003, año del retiro de la abogacía, fue asesor en asuntos penales de un importante banco del país.

57 Diez años antes había impartido otro, sobre problemas modernos de los delitos contra la vida y salud humanas, en la sede de Valparaíso de la Universidad de Chile.

${ }^{58}$ Como la recuperación de la nacionalidad española, que data de 1980.
} 
GUZMÁN DALBORA, José Luis “Un penalista en pugna con los lugares comunes: Francisco Grisolía Corbatón (1928-2005). Estudio necrológico"

La proximidad de la muerte parece haber sido un aliciente para producir más en la ciencia $\mathrm{y}$, simultáneamente, denunciar la proyección jurídica, inadvertida por los mismos jurisconsultos, de los lugares comunes que lastran a la sociedad chilena, en la que prejuicios y frases clichés disimulan irritantes desigualdades, con los privilegios que medran de su perpetuación. $^{59}$ El cariño por la segunda patria seguía conviviendo con el nervio del español, sólo que ahora éste se crispa hasta el punto de galvanizar en los últimos escritos el pensamiento de una famosa paisana, según la cual "el amor a la patria se prueba sirviéndola, y mal sirve al país como a su amigo, quien, por no disgustarle, en vez de señalar sus faltas, las halaga; en vez de acusar, oculta y desfigura o calla la verdad, como si la vergüenza estuviera en que se diga el mal y no en hacerle". 60

Sea mencionado en primer término el artículo sobre la estafa procesal, ${ }^{61}$ que reproduce la conferencia que del mismo tema pronunció el autor, ya jubilado de la Facultad, en el colegio de abogados de Valparaíso el día 27 de mayo de $1994 .^{62}$ De ahí la brevedad de la relación, la cita elíptica de las fuentes bibliográficas, todas ellas españolas, y el timbre del discurso, por momentos, ardiente, como en la frase inaugural: "Misérrima visión es la de quien no es capaz de reconocer todas las posibilidades de la Parte especial del Derecho penal". El asunto, prácticamente desconocido entonces en el medio chileno, que tolera la estafa procesal como persiste en el amparo de la desfiguración forense de las defraudaciones, ${ }^{63}$ lo conocía bien por su experiencia como abogado dictaminador para causas civiles en que una o entrambas partes engañan al juez con el propósito de causar un perjuicio patrimonial a la contraria o a terceros. Las prietas líneas del ensayo demuestran la relevancia típica de este abuso, una estafa agravada que encaja en el Código pese a no consultar éste una hipótesis ad hoc en su incontenible casuismo de las de fraude. Amén de una persuasiva ilustración de la tesis central, para la que emplea como hilo conductor el ejemplo de juicios laborales o ejecutivos simulados por las partes, Grisolía maneja con habilísima mano los elementos estructurales de esta variedad, explicando que el engaño al juez es aquí un fenómeno tan psicológico como en otra cualquiera de estafa, ${ }^{64}$ la

\footnotetext{
${ }^{59}$ En el Derecho, esto vale ante todo para las ramas constitutivas de bienes jurídicos, en lo que la mente vuela de inmediato hacia los ámbitos civil, laboral y procesal, sin olvidar la zona más sospechosa, la constitucional. Pero dada la naturaleza garantizadora del Derecho punitivo, los vicios contraídos en aquéllas repercuten forzosamente en éste.

${ }^{60}$ ARENAL, Concepción Obras completas. 23 vols. Madrid: Librería de Victoriano Suárez, $1^{\text {a }}$ ed., 18941897, t. X (Las colonias penales de la Australia y la pena de deportación), 1895, p. 133.

61 "La estafa procesal en el Derecho penal chileno", en la Revista Chilena de Derecho, publicación de la Pontificia Universidad Católica de Chile, Santiago de Chile, vol. 24, número 3(1997), pp. 417-422.

${ }^{62}$ Conservo una copia del original de la conferencia, de 19 páginas escritas en ordenador. Me la proporcionó mi maestro, Manuel de Rivacoba, quien acompañó a Grisolía en la oportunidad.

${ }^{63}$ Esto es, las denuncias y querellas por estafa, apropiación indebida y otros fraudes como medio con que forzar, a través de la coerción del proceso penal, el cumplimiento de simples obligaciones civiles que el deudor dejó insatisfechas.

${ }^{64}$ Pues hay que distinguir "la imagen normativa del magistrado y la del juez empírico encarnado en la función jurisdiccional práctica. Mientras que el abuso del juez, como personificación del Poder judicial, origina un ataque a la Administración de Justicia, la inducción al juez de la experiencia se encuadra en el tipo de la estafa cuando causa una lesión típica al patrimonio". "La estafa procesal en el Derecho penal chileno", cit. nota n ${ }^{\circ}$ 61, p. 417. Esta afirmación, por demás certera, es característica del neoclasicismo en que se formó el autor. La suposición de que el juez puede ser engañado por las partes sólo a causa de su función, o sea, normativamente, y no en términos psicológicos, la rebatirá cualquier abogado familiarizado con la práctica forense, cuyo era el caso de Grisolía.
} 
Polít. crim. Vol. 6, No 12 (Diciembre 2011), Doc. 1, pp. 474 - 494.

[http://www.politicacriminal.cl/Vol_06/n_12/Vol6N12D1.pdf]

antijuridicidad de las afirmaciones conscientemente falsas del autor o los coautores mediatos del delito, el carácter dispositivo-patrimonial del fallo y el momento consumativo, que en su opinión se produce cuando la sentencia queda en condiciones de cumplirse. Conciso y rotundo a la vez. ${ }^{65}$

Comparado con el anterior, el trabajo sobre las asociaciones ilícitas tiene un sentido distinto. ${ }^{66}$ Era la ocasión de reducir a su correcto alcance un delito sumamente dudoso, que desde la negra cuna en la Restauración, cuando los gobiernos europeos salieron a la caza de enemigos políticos so capa de congregarse éstos en asociaciones perniciosas para el orden público -las llamadas "sociedades secretas", como los carbonarios de la primera etapa del constitucionalismo italiano- ${ }^{67}$ pasando por el temor de las modernas dictaduras hacia quienes se reúnen a sus espaldas, llega en el momento actual en el papel de medio con que castigar a agrupaciones de delincuentes comunes cada vez que el ministerio fiscal no tiene pruebas suficientes de los delitos singulares que perpetraron o, si las posee, para abultarles el monto de las penas. Sabedor de estas insidias, que anota a propósito de la atormentada trayectoria de los Códigos españoles, con énfasis en los draconianos preceptos del faccioso de 1944, Grisolía se detiene en el corazón de la figura, la existencia de una organización, requisito que supone permanencia, estabilidad, jerarquía en el consorcio. "No basta, por consiguiente, que se forme una partida de criminales [...] para que tenga aplicación el artículo; es necesario, además, que esa partida constituya un cuerpo organizado con sus jefes y reglas propias". ${ }^{68}$ Por de contado que estaba en lo cierto ${ }^{69}$. Sin embargo, como de las asociaciones criminales no existe huella en el Chile actual -y tampoco podrían darse, vista la robustez del Estado en su faz policial-, siendo preciso remontarse algunas décadas atrás para encontrarlas, ${ }^{70}$ pronto sobrevendrá un conjunto de disposiciones que nuestro autor, para fortuna suya, no alcanzó a leer en el Diario Oficial. Nos referimos a las que han equiparado las bandas a las asociaciones ilícitas, endurecen la responsabilidad de los individuos que delinquen al interior de agrupaciones inorgánicas $y$, en fin, las que se encarnizan penal o procesalmente con pandillas, mejor dicho, con niños. No es de sorprenderse, porque una característica de la legislación de la hora es hacer caso omiso de los científicos y, mucho nos tememos, del principio de humanidad.

\footnotetext{
${ }^{65}$ La cuestión será objeto de un estudio más extenso, que viene a ser el segundo después del que comentamos, sólo varios lustros después. Véase HERNÁNDEZ BASUALTO, "La estafa triangular en el Derecho penal chileno, en especial la estafa procesal", en Revista de Derecho, publicación de la Facultad de Ciencias Jurídicas y Sociales de la Universidad Austral de Chile, Valdivia, vol. XXIII, número 1 (julio de 2010), pp. 201-231.

66 “El delito de asociación ilícita”, en la Revista Chilena de Derecho, vol. 31, número 1 (2004), pp. 75-88.

${ }^{67}$ Interesantísimo al respecto, DE RUGGIERO, Guido, Historia del liberalismo europeo. Traducción de Carlos G. Posada. Edición al cuidado de José Luis Monereo Pérez. Granada: Comares, 2005, pp. $297-303$.

68 "El delito de asociación ilícita", cit. nota n ${ }^{\circ} 66$, p. 82.

${ }^{69}$ Las necrologías no son indicadas para que el biógrafo discrepe del biografiado, quien tampoco podría replicarle. Así y todo, creemos no cometer un exceso al observar que su apego a la dogmática española le juega una mala pasada tanto en el bien jurídico del delito, que él entronca en la libertad de asociación, como al subscribir sin ambages la tesis del concurso real entre la asociación y los delitos particulares de su calendario criminoso.

${ }^{70}$ Sólo que en los crímenes más graves contra la seguridad del Estado.
} 
GUZMÁN DALBORA, José Luis "Un penalista en pugna con los lugares comunes: Francisco Grisolía Corbatón (1928-2005). Estudio necrológico"

La última obra es una extensa monografía sobre la libertad de expresión y el derecho a la honra, que el veterano profesor dedica a sus maestros. ${ }^{71}$ Grisolía aparece de cuerpo entero en ella, comenzando por la revelación del primer párrafo, a saber, que la manida frase de que dicha libertad y, por tanto, la de información, que es una de sus especies, terminan allí donde empieza el derecho al honor, "no es digna de un jurista". 72 A estas alturas, se comprenderá que no le motiva un mero afán iconoclasta ni el prurito de decir cosas sagaces, virtud y pathos del abogado. Aquí habla un científico que se propuso demostrar que en el conflicto entre la libertad de información y el honor de las personas, dos bienes jurídicos constitucionalmente reconocidos, ha de prevalecer en general la primera. Grisolía lo examina en todas sus dimensiones, tanto las que atañen a la libertad de expresión considerada en sí misma -incluyendo el problema de la censura, el secreto de los periodistas y la causa de justificación que los asiste en el ejercicio de su oficio-, como en su dependencia de una teoría política de acendrado liberalismo, a cuya esencia repugnan peticiones de principio como la denunciada en el párrafo inicial, propia de "un país dominado por la pacatería y el tontogravismo". ${ }^{73}$ Bajo ella se oculta la intención de poner a la libertad en palabra la peor mordaza, provista por el brazo armado de la persecución penal, en circunstancias que así se destruye desde la raíz una condición básica del libre comercio de las ideas requerido por toda democracia.

Si el estudio de la libertad de expresión traduce la doctrina constitucional que prohijó el autor, celosa de las condiciones que posibilitan la real autonomía de los individuos y la preservación de una vida organizada en libertad, el del honor y los delitos que lo ofenden, que el libro entreteje con el primero, nos brinda la oportunidad de adentrarnos en la evolución del pensamiento de Grisolía como criminalista. Por cierto, es partidario del concepto normativo de este bien jurídico en cuanto proyección de la dignidad intrínseca de la persona humana. Un espíritu normativo inspira, además, la apreciación del tipo de injusto de las injurias, aspecto capital para fijar el deslinde entre el delito y el ejercicio legítimo de la libertad de informar. El libro descarta que el juicio de antijuridicidad sea aquí de naturaleza híbrida, objetiva y subjetiva a la vez, porque entiende que el animus injuriandi tampoco es un componente de la infracción. Al paso que atribuye al dolo un doble emplazamiento, en el injusto y la culpabilidad, sostiene que ante una expresión objetivamente injuriosa, por ende, típica, la exclusión de lo injusto depende sólo de la concurrencia de los elementos de la eximente del ejercicio de un derecho, que en este caso son el interés público de la información, su necesidad y la actitud positiva del actor hacia la verdad, ${ }^{74}$ nada más.

Sin embargo de lo anterior, no ha de creerse que estas páginas trituren la esfera de intimidad de las personas para que de sus ruinas se yerga victoriosa la libertad de informar... o el lucrativo negocio de la prensa. ${ }^{75}$ El análisis que realiza del delito de

\footnotetext{
${ }^{71}$ Libertad de expresión y derecho a la honra. Santiago de Chile: LexisNexis, 2004. II + 355 págs.

${ }^{72}$ Libertad de expresión y derecho a la honra, cit. nota $\mathrm{n}^{\circ} 71, \mathrm{p} .1$.

${ }^{73}$ Libertad de expresión y derecho a la honra, cit. nota ${ }^{\circ} 71$, p. 143.

${ }^{74} \mathrm{O}$ diligencia en la comprobación de la fuente y la veracidad del hecho informado (verdad subjetiva). Libertad de expresión y derecho a la honra, cit. nota ${ }^{\circ} 71$, cfr. pp. 110-111.

${ }^{75}$ El autor tuvo lúcida conciencia de las amenazas de este y otros lados obscuros de la libertad de prensa como la concentración monopólica de los medios de comunicación y la ausencia de pluralidad ideológica en ellos- para la intimidad individual, como puede verse en págs. 26-33 del libro.
} 
Polít. crim. Vol. 6, No 12 (Diciembre 2011), Doc. 1, pp. 474 - 494.

[http://www.politicacriminal.cl/Vol_06/n_12/Vol6N12D1.pdf]

descubrimiento y relevación de conversaciones, comunicaciones, imágenes o hechos privados, más allá de la pésima redacción del artículo que lo amadriga (161 A del Código penal chileno), es demostrativo del celo de nuestro penalista por el respeto del ámbito íntimo de cada cual. Así se explica que pueda ser sujeto activo quien tomó parte en la conversación o escena, registrándola a hurtadillas del otro, y sujeto pasivo, también un juez $\mathrm{u}$ otro funcionario público en cuyo despacho privado ocurrió la reunión. ${ }^{76}$ Lo que no hay que confundir es el secreto de las personas con el secretismo en las actuaciones procesales, que Grisolía vio reflotar en la investigación de los delitos de blanqueo de bienes de procedencia delictuosa. El desvelo por la publicidad en todas las fases del proceso, así como el cuestionamiento de los métodos de pesquisa fundados en el engaño, la traición y el disimulo, ${ }^{77}$ prolongan aquí, en el último escrito, un proyecto de investigación iniciado cuarenta y tres años antes.

Grisolía había invertido en preparar el libro varios años, ${ }^{78}$ el último de los cuales coincide con el desarrollo de la enfermedad que segó su vida, un cáncer a la próstata. Tan mancomunadas estaban existencia y quehacer científico en este criminalista, que la confirmación del sombrío pronóstico, hasta ese momento incierto, la tuvo precisamente el día de la presentación de la obra al público. Con la labor cumplida, el mal podía ya ultimar velozmente la suya. Francisco Grisolía Corbatón fallece el 4 de mayo de 2005, a los setenta y seis años de edad, en su casa de Santiago. El pensamiento lo querría hoy lejos, recobrada la felicidad de la infancia, en Barcelona.

\section{Balance.}

Aquilatar la contribución a Chile de los emigrados de la guerra española excede el objeto del presente estudio y las fuerzas de quien lo firma. Ni siquiera está en nuestro poder una apreciación global de la individualidad de este emigrante, al que conocimos a través del producto impreso como penalista. Con todo, no hemos de deponer la pluma sin un intento de balance, puesto que lo creado deja intuir el temperamento del creador y porque sus circunstancias personales replican de algún modo las de aquel grupo, con el aporte que estos hombres, o los más conspicuos entre ellos, dieron a la cultura nacional. De la consideración de los factores intervinientes en el proceso puede desprenderse una mirada retrospectiva y otra escrutadora del porvenir.

\footnotetext{
${ }^{76}$ Libertad de expresión y derecho a la honra, cit. nota $n^{\circ} 71$, cfr. pp. 171-174. No así, en cambio, los sujetos que abren voluntariamente el espacio de protección de su honra y vida privada, como las gentes "de la llamada 'farándula' (profesión de los farsantes), que lucran con su intimidad y pudor para deleite de un sensacionalismo barato y mórbido" (pág. 213).

${ }^{77}$ Como valerse de informantes de la policía, es decir, vulgares "soplones" que son generalmente delincuentes que obran por un estímulo en dinero o por pactos de impunidad; introducir en las filas del terrorismo o de la delincuencia organizada "infiltrados" que están, ellos también, obligados a cometer delitos para ganarse la confianza de quienes infiltran. En suma, todo un conjunto de acciones que, obviamente, caen dentro de la ley penal. ¿Puede la ley, a su vez, arreglar esta contradicción tan evidente e insoslayable? Libertad de expresión y derecho a la honra, cit. nota $\mathrm{n}^{\circ} 71$, p. 259. Grisolía opinaba que no, confiando en la teoría de la adecuación social en su función de causa de atipicidad.

${ }^{78}$ A lo menos siete, como se puede deducir del artículo "Libertad de información y derecho a la honra", en la Revista del Abogado, Santiago de Chile, número 10 (1997).
} 
GUZMÁN DALBORA, José Luis "Un penalista en pugna con los lugares comunes: Francisco Grisolía Corbatón (1928-2005). Estudio necrológico"

Grisolía no resultó ser un escritor tan prolífico como algunos miembros de su generación. Sin embargo, el motor interno que movía a todos recibió durísimo golpe, que en muchos sentidos, incluso el literal, representó una cuchillada homicida para la vida del país. La ciencia sólo puede prosperar en un ambiente de libertad, que infunde confianza y optimismo en las personas, siendo una verdadera excepción los hombres que consiguen substraerse a la atmósfera opuesta, de agobio y debilitamiento bajo la tiranía. Esto confiere un valor particular al desempeño de nuestro investigador, así por su trabajo en el Instituto de Ciencias Penales y la calidad de los contados estudios que elaboró entre 1973 y 1990 , como por la paciencia con que sostuvo la carrera universitaria hasta la eclosión final, cuando reaparece con la misma fertilidad productiva de los años sesenta. Si Grisolía publicó menos que otros, eso no se debe a haber descuidado sus deberes como estudioso. Como la mayoría de los chilenos, fue víctima de las condiciones que se apoderaron de todo un período histórico.

Esto aparte, la imagen cuantitativa es en su caso sinónimo de mérito cualitativo. La organización universitaria y el circuito editorial de hoy nos han acostumbrado a un laborío incesante en la ciencia jurídica, pero manteniéndonos ignaros del riesgo de transformarnos en máquinas que producen objetos en serie, de originalidad anémica y, para colmo, sin atractivo fuera de un grupúsculo de iniciados. La creación intelectual es de suyo demasiado compleja como para hacerla galopar según los plazos y el rendimiento que aguardan sus modernos e interesados mecenas. Al revés, demanda tiempo, meditación, independencia, variedad, porque sólo con estos ingredientes el investigador crece y su rendimiento objetivo puede aspirar a alguna conquista, como las que consiguió el pausado Grisolía, al margen del carácter definitivo o provisional del logro. Tuvo parte en ellas la aversión del autor por la especialización, mejor dicho, la especialización llevada al extremo dentro de su coto científico, el Derecho penal. Si la especialización, pesada rémora de la época del positivismo, conspira contra la formación del verdadero jurista, que ha de serlo precisamente porque ningún problema ni sector del ordenamiento le son ajenos, aún más nociva es la hiperespecialidad, la unilateral concentración en un segmento aislado de la ingente materia. La hiperespecialización debe considerarse una enfermedad que devora gradualmente al estudioso, hasta que llega el instante en que de él no resta ni siquiera el especialista, menos aún el hombre que se licenció en la universidad y podía entregar una respuesta en sus materias como las que otrora daba a sus pacientes el médico general. No es hoy misterio alguno que la especialización médica puede agravar al paciente, incluso quitarle la vida, a resultas de la limitación del campo diagnóstico y del saber clínico del galeno.

En fin, el meditado adelanto y la amplitud temática que trasparecen en los escritos de Francisco Grisolía, se alían con esa faceta del individuo que dio el punto de arranque a este repaso de su periplo. El aborrecimiento de los lugares comunes, en un país que acaricia como preciada joya las frases estereotipadas, es una actitud indispensable para la mejora de nuestro Derecho penal, remover el anquilosado ordenamiento jurídico en su conjunto y, sobre todo, la renovación de la sociedad chilena. En la empresa de liberarla de las cadenas del inmovilismo, de desembrollar el ovillo declamatorio, la palabrería que encubre las contradicciones del medio en que trabaja el jurista, corresponde prominente lugar a uno que 
Polít. crim. Vol. 6, No 12 (Diciembre 2011), Doc. 1, pp. 474 - 494.

[http://www.politicacriminal.cl/Vol_06/n_12/Vol6N12D1.pdf]

nos contempló con ojos de español, vehemente, severo, antipático en ocasiones, pero leal, noble y honesto. 